\title{
Revisiting the Educational and Literary Activities among the Jewish Women of Calcutta
}

\author{
Kaustav Chakrabarti ${ }^{1}$ \\ ${ }^{1}$ Asst. Professor, Department of History, City College, Kolkata-9, India \\ Correspondence: Kaustav Chakrabarti, Asst. Professor, Department of History, City College, Kolkata-9, India.
}

Received: November 14, 2016

Accepted: November 22, 2016

Available online: February 23, 2017

doi:10.11114/ijsss.v5i3.2241

URL: http://dx.doi.org/10.11114/ijsss.v5i3.2241

\begin{abstract}
The Jewish women of Calcutta contributed extensively towards building and consolidating the rich socio-cultural heritage through the creation of social and cultural infrastructures like schools, hospitals, baby clinics, women and youth organizations. Breaking social taboos, they were stimulated by the attractions of western education and took up modern professions. Their contributions were keenly appreciated both in pre-and post-independent India, which this paper tries to explore. Moreover, when India is delving into the rich diversity of its different voices, with women and environmental issues coming to the fore, the contribution(s) of the Jewish women, as the "other voice of history" could hardly be ignored. Thus besides highlighting the different aspects of the world of the Jewish women of Calcutta and their contribution in the literary-educational field, the paper also tries to fit their collective experience in a multi-cultural rubric, in the Indian context.
\end{abstract}

Keywords: Jews, women, education, Calcutta

\section{Introduction}

The city of Calcutta is home to a tiny community namely, Baghdadi Jews from the Middle East. They arrived in India in the eighteenth and the nineteenth centuries. Coming mostly from Baghdad and Basra, they settled initially in the western Indian port-town of Surat that had a flourishing trade and commerce with West Asia and had merchants from practically all the trading nations in the region. However, as the importance of Surat declined over time, they moved out to the fast-growing commercial centres of Bombay (Mumbai) and Calcutta (Kolkata). The Sassoons of Bombay and the Ezras of Calcutta virtually dominated the economic and cultural lives of their respective communities.

Calcutta, for a long time, has had the reputation of being the cultural capital of India. This was primarily owing to the presence of a large number of educational institutions that contributed not only to the spread of knowledge among the city's inhabitants, but also contributed greatly to the task of national regeneration. Calcutta, being a colonial city and once the second largest city of the British Empire, was the earliest recipient of Western education. Practically all the ethnic communities made an effort towards the task of educating their brethren. Though Christians had a preponderant say in the field of public instruction, yet one community made all possible effort in taking advantage of the new mode of knowledge. This was the Jewish community of Calcutta.

\section{The Antecedents}

\subsection{The Socio-Cultural World of the Jews of Calcutta}

Commercial success apart, it is the socio-cultural world of the Calcutta Jews, which is the most fascinating. The Jewish community of Calcutta was tightly organized. The community provided every member sacramental wine from its winepress, bread from its bakery, chicken from its slaughterhouse, education from its schools and even paid employment in its services.

\subsection{The Family}

In attempting to capture the identity of a people, we first look into its heart-the family. The joint family system was a common feature of life in the Middle East and among the Oriental people, the Jews were no exception either. The traditional Middle Eastern Jewish family, like its Muslim counterpart was extended, endogamous, patriarchal, patrilineal and occasionally polygynous. 
Oriented towards the past, these families were organized into large households. These large households consisted of the principal couple, their children, some married with children of their own, unmarried sisters or bothers of the couple and any aged parent who might still be living. By 'family', the married ones automatically included their parental family and those grand-parents who lived with them. In general, the whole family sat at one table, although as the twentieth century progressed, they might have ordered individual meals from the same cook or in some cases have had completely separate establishments including their own kitchen while living in the same house. The extended family was a central part of each person's daily experience. ( Kazzaz David (2001) Cousins did not just visit on a holiday or special occasion but saw each other everyday. (Kazzaz David (2001) They played, fought, and argued together like siblings. (Kazzaz David (2001) ${ }^{1}$ And, when a Jewish holiday was round the corner, every member of the family eagerly participated in the preparations. (Kazzaz David (2001). The extended family gave community members a sense of security. Even the adolescents might have benefited from it. It is the only young married couple wanting to spread their wings and start a family who would have found the joint family system irksome. If the pressures became unbearable, a couple could solve the problem by moving into a household of their own while maintaining ties with the parental family. A child's welfare was the concern of the whole family. A verbal reprimand or even physical punishment was not uncommon from grandparents or aunts of the older members of the community. In a community as rigidly patriarchal as the Jewish, there was no distinct dichotomy between male and female roles. The role and status of each member was defined in strict details. Higher status and authority went to the males, particularly the head of the household and the eldest son. Females had a lower status, but gained a measure of indirect power through mother hood.

\subsection{The Status of Women}

A noticeable and recurrent feature of Calcutta Jewry even in the days of one hundred percent male dominance was the strength of many of the women it produced. Bound as she was by convention, nevertheless her character developed along permitted lines, and in her own sphere she commanded the respect of her husband, children and the community. She might study Hebrew or the mysteries of the Kabbala (Jewish mysticism) at an advanced stage outstripping her brothers, or else helped her father and husband with their work. In the confines of her home, her intelligence was appreciated and was even used by the men folk to make business decisions. Some women acquired entrepreneurial skills and managed their husbands' estates or businesses in the event of the latter becoming incapacitated.(Silliman $2001)^{2}$ They did so admirably. It might be thought that in a society as rigidly orthodox and patriarchal as the Baghdadi Jews of Calcutta, women would for the most part remain suppressed, and sometimes this did happen, this was not always the case. The community held many women in great esteem whether they were married or unmarried. The cases of women going out on their own were not unheard of. Women worked as piece-good dealers, tailors, general merchants, shopkeepers and domestic help. Four women were teachers. There were seven prostitutes and five women who were singers and actors.(Silliman 2001) $)^{3}$

\subsection{The Jewish Girls'School}

Though a Jewish Community had long been extant in Calcutta, it was only in 1881 that a school came into existence. This was the Jewish Girls' School. The School was founded to counter missionary efforts when it was discovered almost by accident that a Jewish girl was about to be converted to Christianity.(Benjamin Israel (1984) Education of Jewish girls paralleled the development of girls' education in Calcutta.(Silliman 2001) At that time, numerous schools catering to the educational needs for girls were established. Among these were the Juvenile School (1820), Bethune School (1849), Victoria College (1882) and BrahmoBalikaVidyalaya (1890). The poorest in the Jewish Community attended the Old Mission School. In part, the Jewish Girls' School was opened so that the girls in the community would not fall prey to Christian/proselytizing influence. The School initially set up at Ezra Street moved to a rented accommodation in the Pollock Street. As the need and demand for a building of their own grew, contributions were raised largely through the efforts of the Rev E.M.D. Cohen, and the foundation of a new building was laid on the same premises in 1926 by Sir David Ezra. His wife Lady Rachel placed with it, in a vacuum jar, two gold, four silver, four nickel and four copper coins, a scroll recording the proceedings on specially prepared parchment, an engraving of Jerusalem, copies of the speeches and issues of the day's English-language newpapers. The building was opened three years later by Lady Jackson, wife of the Governor of Bengal Sir Stanley Jackson. ${ }^{7}$ With Pollock street having become an impossible snarl of congestion and the Jews having long ago moved out of the area, in 1955 the School shifted yet again to its - present premises on Park Street. In 1962, they got a new building there. Miss Duffin was the first Headmistress followed by Miss Bryning and thereafter Miss Regina Guha, the first Jewish Headmistress. She consolidated the gains of her predecessors and introduced modernization.

The School was run by the Reverend E.M.D. Cohen, rabbi of the Maghen David Synagogue and editor of the journal Paerah. Among the other benefactors of the institution were Moses Jacob Abeasis, Moshe Mayohas, and RahamimMoosa Cohen.(Shema, 1956) The School had a kindergarten for three-year olds plus an additional nine grades. In the seventh grade, the girls had to pass a Junior Cambridge Examination, which was administered from and corrected 
in Cambridge, England. Similarly, in the ninth standard, and to finish high school, they had to pass Senior Cambridge. The Jewish Girls' School was noted for the excellent performance of its candidates and several came out with flying colours in the examinations. In 1936, the best results in Bengal for the Cambridge Examination went to the Jewish Girls' School, which sent seven girls for the Senior Cambridge, all of whom passed, and, three out of four for the Junior Cambridge. The successful candidates were-

Senior Cambridge: Ruby Gubbay, Mercia Rassaby, Sally Twena, Hannah Moses, Sarah Meyer, Mercia Abraham, Helen Rassaby; Junior Cambridge: Myrtle Abraham, Ramah Elias, Ethel Isaac. Among the distinguished alumni of the School was Matilda Cohen, the first Jewish Girl to receive the Master's Degree from the University of Calcutta. The School had its own magazine entitled Excelsior. Though the Jewish Girls' School prepared the students for college, most of the girls did not pursue a higher education. They opted for vocational training classes to become teachers, secretaries, nurses, hair dressers, and joined other professions that were considered suitable for women in those days. One respondent, formally a teacher of the Jewish Girls', replied, "I finished my education at the age of fourteen". The students at the Jewish Girls' School were all Jewish, as most of the Staff, except a few Anglo-Indian teachers. Regina Guha, the sister of Hannah Sen (nee Guha), was the first Jewish Principal of the School. It attained the highest intake of Jewish pupils during the time of Miss Ramah ("Ramoo") Luddy who served as the Principal of the School for thirtyfive years from 1928 to 1963. School hours at the Jewish Girls' School were from nine in the morning to three in the afternoon, but school work did not end there. Homework was a regular and daily feature of life, taking at least two hours a day from the first standard. Besides English serving as the first language, the second language was French, and the students learned to read and write enough Hebrew to be proficient at their prayers.

Miss Luddy, the Principal of the School maintained a very high standard for which it was renowned in the community. "Not Failure But Low Aim is Crime" ran the motto of the School. This is what a community member had to say about the standard of its teachers-

"When I took the tram from office on my way home, I used to sort of eavesdrop on the conversation of the teachers of the Jewish Girls' School. They were very informative and covered every aspect of knowledge. It was as if these teachers had dedicated themselves to the well-being of the students and that of the community at large. It was a treat to hear them out".

The early settlers of the community were not well educated. They knew just enough to carry on their day-to-day business. Formal education among the older members of the community usually stopped at fifteen or sixteen. Academic qualifications were not considered necessary to the main business of life. In fact, instances of dropouts were not rare. In contrast to the old timers, many members of the younger generation went out into the world to make their own fortunes on completion of college education. By that time onwards, higher education began to be seen as a passport for a better life and overall progress of the self and community. The majority of graduates worked in the concerns of the Jewish firms like David Sassons'; E.D.Sassoons'; Curlender's and B.N.Elias's. The B.N. Elias and Co. was by far the largest employer of Jewish professionals in Calcutta and the neighbourhood. Jewish men worked as clerks, assistants, managers and even directors in these organizations. According to Thomas Timberg, "There were very few Jewish professional men. This was in sharp contrast with the Armenians of Calcutta. For instance, we have a list of 25 Armenian High Court Advocates between 1855 and 1891, 8 Solicitors (1856-91) and six doctors in the Indian Medical Service. The 1915 Thacker's lists four Jewish barristers and one solicitor." Timberg further observes that, "The rate of literacy was also much higher among Armenians than Jews-86\% in 1911 compared to 60\% among Jews." (Thomas Timberg: Jews in India, Vikas Publications, New Delhi, 1986, p.34)

Since 1891, female education made satisfactory progress among the Jews. The distribution of literate male and female population among the adherents of Jewish faith in 1901 as compared with 1881 and 1891 is as follows:

Table 1. Percentage of Literates

\begin{tabular}{lccc}
\hline JEW & 1881 & 1891 & 1901 \\
\hline MALE & 63.5 & 62.9 & 65.9 \\
FEMALE & 29.3 & 36.2 & 44.8 \\
\hline
\end{tabular}

Source: Census of India 1901, Vol.8, Part IV Report (Statistical): Calcutta Town and Suburbs by J.R. Blackwood, p.57

Taking both the sexes together, about $69.3 \%$ of the Jews were literate in Calcutta and the suburbs. By 1921, majority of the Jews could read and write English.

While the poor and the middle class girls attended the Jewish Girls' School, the daughters of the wealthy attended schools like Calcutta Girls', Welland Goldsmith and later, Loreto House.

One of the remarkable features of the Jewish community in Calcutta was the large number of educated and strong-charactered women it produced. The growing emancipation of women in the Calcutta Jewish community was an 
indicator of social activism and rising social consciousness among the youth. The first stirrings of female emancipation from the strait jacket of home and family were felt in the community and Jewish women following the lead given by their unshackled sisters in Europe and America started to take up jobs and think of self-reliance. It was then that the majority of Jewish girls who wished to take up secretarial work after leaving school met with parental opposition. But the battle was soon lost to the youngsters and by the 1930s, Jewish girls were much in demand in the business world of Calcutta. Stella Benjamin was an MA of Calcutta University, for several years taught at the Jewish Girls' School, then joined the Bengal Chamber of Commerce, the first woman to hold an executive position there. She immigrated to England in the 1950s. Rachel Duek Cohen was the first lady doctor in the Jewish community of Calcutta. She enrolled into the Calcutta Medical College in June 1892 for L.M.S and M.B. courses at Government Scholarship of Rs. 20/.Rachel Duek Cohen was attached with the Jewish Baby Welcome Clinic started by the Jewish Women's League in Calcutta and together with Miss Hannah Ephraim and Dr. EnaMitra, rendered valuable service to poor and destitute children and their parents. She immigrated to England in the 1930s. NiutaGhosh was born in Bialystock, Poland and got her education in Germany and France, where she studied at the Pasteur Institute. Her father, a well-known chemist, was the first cousin of Dr. Zamenhof, inventor of Esperanto and of ManyaWilbushewitch-Shochat, one of the first and most prominent women pioneers of Israel. ${ }^{25}$ Mrs. Ghosh was on the Calcutta ORT Committee and was connected with charity work. She took over the OSE (Oeuvre de Secours aux Enfants= Institution for Childhood Assistance) work in 1948 from Mrs. Jo Farbstein who started the work in Calcutta. The OSE was set up to provide assistance to children who survived the Holocaust by establishing and organizing children's homes, kindergartens, orphanages, sanatoria and other institutions. By the generous support of the American Jewish Committee through the American Jewish Joint Distribution System and other Jewish organizations throughout the world, it was possible to undertake such a gigantic task. The Calcutta chapter of the OSE, through the energetic efforts of Mrs. Ghosh, tried to enlarge the number of sponsors and donors. By the early 50s, 41 children found sponsors in Calcutta alone. Rachel Ashkenazi was the first lady lawyer in the community to practice at the Calcutta High Court. She pleaded for Muslim women who had to go about in Purdah (veil). Miss Queenie Cohen of Calcutta was the first Jewess from India to be a barrister. She passed the final examination from Lincoln's Inn and was called to the Bar. The Jewish women of Calcutta excelled in studies and many made a mark for themselves in the academia. Miss Hannah Cohen, Miss Seemah Duke and Mr. Ezra Gubbay all passed their pre Sci MBB examinations. Miss Hannah Moses and Miss Seemah Cohen passed the ISC. Miss Seemah Cohen, a former pupil of the Jewish Girls' School, completed her course in one year gaining a scholarship of Rs. 50/-. Among those who passed the B.A. Examination, University of Calcutta, Mrs. S. Isaacs got the Second Division. She pursued her studies while continuing her work as a teacher in the Jewish Girls' School. She won the gold medal for English Composition. Miss Daisy Jacob passed the B.A. Examination, standing first among the girls of her college, while Moses Levi, a student of St. Xavier's' came first in the Second Division. Miss Iris Moses, B.A. , B.T. (Calcutta University) was the Lady Principal of Sir RomeshMitter School Bhowanipur. She was also Girl Guide Captain Calcutta, $8^{\text {th }}$ Company. In 1953, she and her husband Eddie Ferris, a locomotive driver immigrated to England with their son Dan. Iris became immersed the Girl Guides Movement of England and rose to a high position in its London headquarters. Ramah Khatoon did not marry and became one of the outstanding social worker of the community. For many years she taught at the Jewish Girls' School, her principal subject being French. She was instrumental in setting up the Jewish Girls' Hostel. The Hostel was opened officially on December 26, 1937. For several years, the services of Anne Othoneos(Born Kate Judah in Singapore) as superintendent were invaluable. The Girls' Hostel was to ultimately become the foster child of the Jeshurun Free School, developing into its boarding department and fed by generous endowments. Ramah Musleah decided not to marry and dedicated her life to teaching, a profession she cherished all her life. Tabby Solomon became a dentist; and Sarah Abraham became a math teacher at the Jewish Girls' School after training at a teachers' seminary in Dow Hill Kurseong, West Bengal, and subsequently continued teaching when she emigrated to London.

Hannah Sen, the daughter of P.M. Guha, an eminent Bengali lawyer, and married to SeemahGubbay of the Gubbay family of Calcutta, was a brilliant and talented woman. She was educated at the Pratt Memorial School and later at the Diocesan College where she took the degrees of B.A. (Hons) and B.L. (First Class) of Calcutta University. After graduation in Law, Hannah Sen took up profession as an educator. She was permitted to sit for the B.A. Examination after qualifying Senior Cambridge without having to go through the F.A. Examination. After a stint at the Jewish Girls' School in Calcutta, she went to Bombay and took up the post of Principal (the first Indian Principal) of the New High School for girls. She worked there till 1925. Later in 1925, she married Dr. Sen, an eminent radiologist. It was in Bombay that Mrs. Sen met many of the leading personalities of the time. Among the most notable of these was India' greatest woman poet, Mrs. Sarojini Naidu with whom she became a close friend. Soon after their marriage, Dr. and Mrs. Sen went abroad for further studies. Hannah took her Teacher's Diploma at the University of London where she later became a Research Scholar in Psychology under Prof. Spearman. Persuaded by Sarojini Naidu, on the plea, that she should further the development of Indian women, Mrs. Sen returned to India and assumed the post of Directress of Lady Irwin College, New Delhi, whilst Dr. Sen gave up his successful career in London and set up practice in New Delhi. Thanks to her tremendous zeal for work, 
the tiny college of 1932 that started only with eleven students soon blossomed into a major institution of repute imparting training to hundreds of women every year. It was during these fruitful years that Mrs. Sen came into contact with the leading lights of Indian nationalism like Mahatma Gandhi, Jawaharlal Nehru, VijaylaxmiPandit, besides Lord and Lady Mountbatten, Madame Chiang Kai-Shek, and many more luminaries. When she resigned from Lady Irwin, she served in honorary capacity to the Ministry of Relief and Rehabilitation of the Government of India, and she shared with Mrs. Rameshwari Nehru, the task of advising the Ministry in all matters pertaining to the relief and rehabilitation of displaced women and children.

Closely associate with her domestic activities were her wider interest in activities abroad. She was one of the Observers of the All India Conference of Social Work held in New York in 1948.

As a member of the Executive Board of the Indian National Commission of UNESCO and as Honorary Secretary of the Indian National Committee of the United Nations' Appeal For Children. As an activist on women's issues, she represented India on the UN Commission on the Status of Women in 1950 and 1951. Mrs. Sen was also present as the leader of the Indian Delegation at a meeting of the International Union for Child Welfare held in London in July 1950. She was member of the Indian Delegation to UNESCO held in Paris in 1951 and a member of the Indian Goodwill Mission to China the same year. ${ }^{55}$ It was women like Mrs. Hannah Sen who cemented friendship between India and the rest of the world. A sense of world citizenship, a deep intuitive understanding, a charming personality, a keen intellect, and a crystal-clear mind- these were but a few of the invaluable qualities associated with Hannah Sen. Her elder sister Regina Guha (better known to the Calcutta Jewry as one of the earliest Principals of the Jewish Girls' School) had the distinction of being the first woman to take up law in Bengal after obtaining the first place in the first class of her M.A. degree in English at the Calcutta University. For a long time, there was a medal bearing the name of Regina Guha awarded each year to the candidate securing first place in English in the M.A. Examination. After successfully completing her legal studies, Regina sought to follow her father's footsteps and practice Criminal Law.India, at that time was not prepared to admit practicing women lawyers to the Bar. Regina was however determined to fight against this conservative attitude and instituted a case against the Calcutta High Court thus writing a new chapter in legal history. The Chief justice at that time was Sir Asutosh Mukherjee, while Lord Sinha as Advocate General defended the action of the High Court. Regina's case was presented by Erdley Norton, the intellectual genius of the legal world. In the face of the law as it stood it was a foregone conclusion that she would lose the case. However, she succeeded in focusing the attention of the public both in India and abroad of the disability Indian women underwent because of the narrow-minded conservativeness of the time. It was not very much later that the law was revised and women were accorded the right to practise in the law courts of India. Unfortunately, Regina died too soon to avail herself of the privilege.

On the whole, whatever may have been the socio-economic differences in the community, the sense of fellow feeling outweighed all petty considerations as each and every member strove towards its betterment, albeit, within his or her means. The sense of being Jewish dissolved all artificial barriers, because to every member, the community was 'home'. In this respect welfare and philanthropy alongside education took the center stage, in which women played a seminal role. Education proved not only a window to the outside world, but also a ticket to freedom and dignity within the constraints a patriarchal society. Apart from the examples set by the Hindu and Christian communities in their endeavour to educate their women in keeping with the changing times, the Jewish community of Calcutta also took heart from the winds of change sweeping across the Diaspora particularly in the West. As the Western Jews tasted the fruits of emancipation and civil rights in their countries of residence and counted women as co-equal with men in their bid to create a better society, the Jewish community of Calcutta, although suffering no discrimination in British India, nevertheless were eager to get out of the inertia and prove themselves to be responsible and progressive citizens of the country. In this effort, the education of women and the role they played proved to be an event of great significance. Thus when India attained independence and Israel attained her statehood, this intellectual capital proved to an asset of immeasurable consequence. 
Appendix

\section{BIOGRAPHICAL SKETCH OF RAMAH LUDDY}

Ramah Luddy served as the principal of the Jewish Girls' School for twenty-eight years (1935-1963). Apart from her role as a teacher, she served the community in other fields as well. Under the guidance of St.John's Ambulance, she did voluntary work in the out patients' department of a hospital and also at the first baby clinic started by the Red Cross in Calcutta. After completing her training as a teacher in England, she started a Jewish Company of Girl Guides in the East End (with a substantial Jewish population) of London. She joined the University of London's Jewish Students Union. From then on she became an active Zionist. Soon after her return to Calcutta in 1929, she was appointed honorary treasurer of the Jewish Women's League. She organized the League's Baby Clinic (later known as the Jewish Baby Welcome) and she and Miss Marie Mordechai were its first honorary secretaries. In 1929, she founded the Judean Club. The Club organized the first Hannukah party for underprivileged Jewish children. During the Second World War, the club became a meeting place for Jewish (American and British) servicemen in and around Calcutta. A canteen sponsored by B.N. Elias\& Co. was opened during the War and it was Ramah Luddy who made all the necessary arrangements for its successful functioning. In 1945, she organized the Young Peoples' Congregation with the help of Rabbi David J. Seligson, a Jewish chaplain with the American forces in Calcutta. A few years after her retirement from the Jewish Girls' School, she embarked upon a new vocation: She started a Hebrew class for young Jewish children. The classes came to an end when there were no Jewish children in Calcutta to teach.

Source:

Esmond David Ezra: Turning Back the Pages A Chronicle of the Calcutta Jewry, England, 1986

Jael Silliman: Jewish Portraits Indian Frames Women's Narrative From A Diaspora of Hope, Calcutta, 2001

\section{Suggested Bibliography}

Abraham, S. I. (1969). Origin and History of the Calcutta Jews (Calcutta: SenDaw \& Co).

Benjamin, I. (1984). The Bene Israel of India.

Brown, M. J. (2007). Global South Asians Introducing the Modern Diaspora, Cambridge University Press.

David, E. E. (1986). Turning Back the Pages A Chronicle of the Calcutta Jewry, 1 (England: Macmillan).

Hyman, M. (1995). Jews of the Raj (Bristol: University Press of New England).

Isaac, I. A. (1917). A Short Account of the Jews of Calcutta with a sketch of BeneIsraels, the Cochin Jews, the Chinese Jews and the Black Jews of Abyssinia, Calcutta.

Musleah, E. (1975). On the Banks of the Ganga The Sojourn of the Jews in Calcutta, (Massachusetts: Christopher Publishing House)

Parasuram, T. V. (1982). India's Jewish Heritage, New Delhi: Sagar Publications.

Shukla, S. (2005). India Abroad Diasporic Cultures of Postwar America and England ( Hyderabad: Orient Longman (India))

Silliman, J. (2001).Jewish Portraits Indian Frames Women's Narrative from a Diaspora of Hope ( Calcutta: Seagull books).

\section{Archival Works}

Files of the American Jewish Joint Distribution Committee, Jerusalem, Israel.

Home Dept (Political Files) (West Bengal State Archives), Kolkata, India.

Kol Shofar (Various Issues), The Ben Zvi Institute, Jerusalem, Israel.

Shema (Various issues), The Jewish National Library, Jerusalem, Israel.

The Jewish Advocate (various issues), The Jewish National and University Library, The Hebrew University of Jerusalem, Israel.

The Jewish Tribune (Various issues), The Jewish National and University Library, The Hebrew University of Jerusalem, Israel.

\section{Copyrights}

Copyright for this article is retained by the author(s), with first publication rights granted to the journal.

This is an open-access article distributed under the terms and conditions of the Creative Commons Attribution license which permits unrestricted use, distribution, and reproduction in any medium, provided the original work is properly cited. 